\title{
PENGARUH VARIASI JENIS LIMBAH SAYURAN (KUBIS, SAWI, SELADA) DAN KADAR EM4 PADA PEMBUATAN PUPUK KOMPOS DENGAN PROSES FERMENTASI
}

\author{
THE EFFECT OF VARIATIONS OF VEGETABLE SOLID WASTE TYPES (CABBAGE, \\ MUSTARD, LETTUCE) AND EM4 LEVELS ON COMPOSTING WITH FERMENTATION \\ PROCESS
}

\author{
Harimbi Setyawati *, Sanny Andjar Sari, Devona Nathania K, Nadila Zahwa A \\ Program Studi Teknik Kimia, Fakultas Teknologi Industri, Institut Teknologi Nasional Malang, Jl. Karanglo \\ KM 2, Malang, 65143, Indonesia \\ *Email: harimbi@lecturer.itn.ac.id
}

\begin{abstract}
Abstrak
Pasar tradisional setiap harinya menghasilkan sampah atau limbah sauran, diantaranya kubis, sawi dan selada juga sayuran yang lain dalam jumlah yang cukup besar dan atau banyak. Sehingga perlu diterapkan suatu teknologi untuk mengatasi sampah atau limbah sayuran tersebut, yaitu dengan menggunakan teknologi daur ulang, merubah sampah sayuran menjadi pupuk kompos yang lebih mempunyai nilai jual dan juga nilai guna yang tinggi sebagai pupuk penyubur tanaman alami. tanpa bahan kimia. Penelitian ini bertujuan untuk mengetahui pengaruh variasi jenis limbah sayuran dan kadar EM4 pada pembuatan pupuk kompos dengan proses fermentasi. Variabel yang digunakan adalah kadar EM4 : $2 \%, 3 \%, 4 \%, 5 \%$, dan $6 \%$ dan jenis limbah sayuran yang digunakan yaitu limbah sayur kubis, sawi, dan selada. Bahan-bahan tersebut dimasukkan kedalam polybag dan dilakukan proses fermantasi anaerob selama 14 hari, yang selanjutnya setiap 2 (dua) hari sekali dilakukan pengecekan suhu dan $\mathrm{pH}$. Didapatkan hasil analisa terbaik untuk kandungan nitrogen pada variasi limbah sawi dengan konsentrasi EM4 6\% yaitu sebanyak $1,06 \%$, untuk kandungan fosfor tertinggi pada variasi limbah kubis dengan konsentrasi EM4 5\% sebesar 0,3\%, kandungan kalium tertinggi pada variasi limbah kubis dengan konsentrasi EM4 4\% sebesar 2,12\%.
\end{abstract}

Kata kunci: Pupuk kompos, Fermentasi, Nitrogen, Fosfor, Kalium

\begin{abstract}
Traditional markets produce solid vegetable waste every day, including cabbage, mustard greens and lettuce as well as other vegetables in large quantities. Therefore, a proper technology needs to be applied to deal with the solid vegetable waste. The technology is the recycling technology, that is converting vegetable waste into compost which has more selling value and high use value as natural plant fertilizer without any chemicals. This study aims to determine the effect of various types of vegetable waste and levels of EM4 on composting by the fermentation process. The variables used were EM4 levels $2 \%, 3 \%, 4 \%, 5 \%$, and $6 \%$ and the types of the solid vegetable waste used were cabbage, mustard, and lettuce vegetable waste. These materials were put into polybags. The anaerobic fermentation was carried out for 14 days, which every two days was checked for the temperature and pH level. The best analysis results for nitrogen content were obtained in the variety of mustard solid waste with a concentration of EM4 6\%, which was $1.06 \%$. The highest phosphorus content was found in the variety of cabbage solid waste with 5\% EM4 concentration, which was $0.3 \%$. while the highest potassium content was found in the variety of cabbage solid waste with EM4 concentration of $4 \%$, which was $2.12 \%$.
\end{abstract}

\section{Keywords: Compost, Fermentation, Nitrogen, Phosphorus, Potassium}

\section{Pendahuluan}

Pupuk kompos merupakan sisa bahan organik yang berasal dari tanaman, hewan dan sampah organik yang telah mengalami proses dekomposisi atau fermentasi. Pupuk kompos terkenal dapat menyuburkan tanaman dan tidak menggunakan bahan-bahan kimia. Penggunaan pupuk kompos menyebabkan tanaman dapat berkembang dengan baik, dikarenakan pupuk kompos merupakan bahan alami yang tidak merusak lingkungan tanah. Mendaur ulang sampah menjadi pupuk kompos mempunyai keuntungan ganda, yaitu pertama kita dapat mengolah sampah secara tepat guna dan yang kedua adalah dengan mengolah sampah menjadi pupuk kompos yang bernilai jual yang cukup tinggi, maka keuntungan secara komersial akan tinggi ${ }^{[2]}$. Penggunaan pupuk 
kompos membantu konservasi lingkungan dengan mereduksi penggunaan pupuk kimia yang dapat menyebabkan degradasi lahan. Pengomposan secara tidak langsung juga membantu keselamatan manusia dengan mencegah pembuangan sampah organik ${ }^{[3]}$. Manfaat pupuk kompos bagi lingkungan sekitar adalah sebagai pupuk organik yang murah dan ramah lingkungan, mengurangi bertumpuknya limbah atau sampah organik yang berserakan di lingkungan pasar tradisional juga tempat tinggal, membantu pengolahan limbah organik secara dini dan cepat, menyelematkan lingkungan dari kerusakan, seperti gangguan bau dan penyakit yang ditularkan dari serangga dan binatang pengerat ${ }^{[4]}$.

Komposisi limbah sayuran hijau yang dapat diolah untuk menjadi pupuk kompos yang memiliki rasio $\mathrm{C} / \mathrm{N}$ kurang lebih 30, dengan kisaran 11-27, dan memiliki kandungan karbohidrat, lemak dan protein yang dapat diuraikan dengan mikroorganisme. Limbah organik dapat diolah menjadi pupuk dengan menggunakan proses fermentasi. Pupuk organik yang dibuat dengan menggunakan proses fermentasi disebut dengan kompos ${ }^{[1]}$.

Fermentasi merupakan proses pemecahan senyawa organik menjadi senyawa sederhana yang melibatkan mikroorganisme, atau jasad hidup seperti bakteri atau jamur yang sangat beperan aktif sebagai bioaktivator ,diantaranya atau salah satunya adalah Effective Microorganisme (EM4) ${ }^{[5]}$. Selain itu proses fermentasi juga melibatkan segala macam proses metabolisme (enzim, jasad renik secara oksidasi, reduksi, hidrolisa, atau reaksi kimia lainnya) yang melakukan perubahan kimia pada suatu subsrat organik dengan menghasilkan produk akhir. Dengan perubahan tersebut maka kadar karbohidrat akan hilang atau turun dan senyawa nitrogen yang larut (amonia) akan meningkat. Dengan demikian, $\mathrm{C} / \mathrm{N}$ semakin rendah dan relatif stabil mendekati $\mathrm{C} / \mathrm{N}$ tanah, dan mikroorganisme mengambil air dan oksigen dari udara.

Beny Suyanto dan Priyono Sigit, tahun 2017 melakukan penelitian pembuatan kompos dengan bahan sampah organiknya adalah rumput, daun sengon dan mangga dan variasi EM4 nya : $2 \%, 4 \%, 6 \%$, hasil yang didapat adalah dengan konsentrasi EM4 sebesar 2\% dan waktu fermentasi 14 hari ,pupuk kompos yang dihasilkan paling baik.

Berdasarkan uraian diatas dapat disimpulkan bahwa sampah organik dengan teknologi daur ulang dapat dirubah menjadi pupuk kompos yang ramah lingkungan dan mempunyai nilai guna dan nilai jual yang tinggi.

\section{Teori}

Kubis (Brassicaolerace) merupakan salah satu jenis sayuran yang banyak tumbuh didaerah dataran tinggi Indonesia. Selama ini kubis dijual hanya sebagai sayuran saja dalam jumlah kecil. Sayuran ini bersifat mudah rusak dan busuk, sehingga menghasilkan limbah (bau) yang menjadi suatu permasalahan dilingkungan. Kubis krop memiliki nilai kandungan organik berupa protein 1,3 gr, lemak 0,2 gr, dan karbohidrat 5,3 gr yang berpotensi sebagai bahan baku pembuatan kompos $^{[6]}$.

Selada merupakan jenis sayuran yang sangat dikenal dikalangan konsumen. Dan selama ini sering dibuat sebagai lalap oleh pedagang makanan. Sayuran ini bersifat mudah rusak dan busuk, sehingga menghasilkan limbah (bau) yang menjadi suatu permasalahan dilingkungan. Sayuran ini memiliki kandungan air yang sangat banyak karena memiliki rasio C/N kurang dari 30 dimana sekitar 11-27. Selada memiliki kandungan protein sebesar $1,2 \mathrm{gr}$, dan fosfor $25 \mathrm{mg}$ tiap 100 gram bahan ${ }^{[7]}$.

Sawi biasanya mempunyai daun yang lonjong, halus, tidak berbulu, dan tidak berkrop. Sampah organik sayur sawi hijau mengandung unsur-unsur yang bisa dimanfaatkan sebagai bahan pembuatan kompos.

Bahan tersebut mempunyai kandungan air yang tinggi, karhohidrat, protein, dan lemak. bahan tersebut juga mengandung fosfor $38 \mathrm{mg}$, besi $2,9 \mathrm{mg}$, kalsium $220 \mathrm{mg}$, vitamin C $102 \mathrm{mg}$ ditiap $100 \mathrm{~g}$ bahan. Semua unsur tersebut mempunyai fungsi yang bisa membantu dalam proses pertumbuhan dan perkembangbiakan tanaman sehingga sangat bagus dijadikan sebagai bahan baku pembuatan kompos organik ${ }^{[8]}$. Dan memiliki rasio $\mathrm{C} / \mathrm{N}$ yang kurang dari 30 dimana sekitar 11-27 karena sayuran mengandung banyak air ${ }^{[9]}$.

Pupuk organik adalah pupuk yang terbuat dari bahan organik atau makhluk hidup yang telah mati, dimana bahan organik ini akan mengalami pembusukan oleh mikroorganisme sehingga sifat fisiknya akan berbeda dari awal pembentukannya. Ada beberapa macam dari pupuk organik salah satunya adalah pupuk kompos, Pupuk kompos adalah hasil dari sebuah pelapukan bahan-bahan dari kotoran ternak, sisa makanan ternak dan lain sebagainnya. Kompos adalah pupuk yang berasal dari sisa-sisa bahan organik yang dapat memperbaiki sifat fisik dan struktur tanah meningkatkan daya menahan air, kimia tanah dan biologi tanah. Proses pengomposan adalah proses menurunkan $\mathrm{C} / \mathrm{N}$ bahan organik hingga sama dengan $\mathrm{C} / \mathrm{N}$ tanah $(<20)$. Selama proses pengomposan terjadi akan adanya jasad hidup seperti bakteri dan jamur yang berperan aktif dalam penguraian ini, dan dengan adanya perkembangan mikroba, banyak ditemukan salah satunya sebagai bioaktivator dalam pembuatan kompos yaitu Effective Microorganisms 4 (EM4), dimana larutan EM4 sendiri mengandung mikroorganisme fermentor yang terdiri dari sekitar 80 genus, dan mikroorganisme ini dipilih agar dapat bekerja secara efektif dalam fermentasi bahan organik ${ }^{[10]}$.

Fermentasi merupakan proses pemecahan senyawa organik menjadi senyawa sederhana yang melibatkan mikroorganisme. Prinsip dari fermentasi adalah bahan limbah organik dihancurkan oleh mikroba dalam kisaran temperatur dan kondisi tertentu. Fermentasi sering didefinisikan sebagai proses pemecahan karbohidrat dan asam 
amino. Karbohidrat terlebih dahulu akan dipecah menjadi unit - unit glukosa dengan bantuan enzim amilase dan enzim glukosidose, dengan adanya kedua enzim tersebut maka pati akan segera terdegradasi menjadi glukosa, kemudian glukosa tersebut oleh khamir akan diubah menjadi alkhohol. Terdapat beberapa faktor yang mempengaruhi proses fermentasi seperti pemilihan substrat yang merupakan bahan baku fermentasi yang mengandung nutrient-nutrient yang dibutuhkan oleh mikroba untuk tumbuh maupun menghasilkan produk fermentasi. Selain itu juga pemilihan mikroorganisme juga berpengaruh dalamproses fermentasi, Pemilihan mikroorganisme tergantung pada jenis substrat, kebutuhan dan produk fermentasi yang diharapkan seperti jenis bakteri (Acetobacter, Lactobacillus, dsb),khamir dan kapang, dimana mikroorganisme tersebut terdapat didalam Em 4, MOL, stardec, dan orgadec. Suhu dan $\mathrm{pH}$ juga berpengaruh dalam proses fermentasi, proses fermentasi dapat dilakukan pada tiga kisaran temperatur sesuai dengan sifat dan karakteristik bakteri yang hadir. Kisaran $\mathrm{pH}$ yang paling efisien untuk pertumbuhan dan aktivitas mikroba berkisar antara 6,4-7,8, maka sering diberi tambahan kapur atau abu dapur untuk menaikkan $\mathrm{pH}^{[11]}$. Arang sekam merupakan bahan pembenah tanah yang mampu memperbaiki sifat-sifat tanah dalam upaya rehabilitasi lahan dan memperbaiki pertumbuhan tanam. Penambahan arang sekam ke dalam media tanam tanah Inceptisols yang memiliki drainase buruk dapat meningkatkan ruang pori total dan mempercepat drainase air tanah ${ }^{[12]}$. Arang sekam mengandung unsur hara $\mathrm{N}$ $0,3 \%, \mathrm{P}_{2} \mathrm{O}_{5} 15 \%, \mathrm{~K}_{2} \mathrm{O} 31 \%$, dan beberapa unsur hara lainnya dengan $\mathrm{pH} 6,8$.

\section{Metodologi Penelitian}

Variabel penelitian

1. Variabel kontrol

- Massa limbah padat

: 500 gram

- Massa arang sekam

: $500 \operatorname{gram}^{[13]}$

- Volume EM4

: $50 \mathrm{~mL}^{[14]}$

- Ukuran Limbah padat

$: \pm 1 \mathrm{~cm}$

- Waktu pengomposan

: 14 hari $^{[15]}$

2. Variabel bebas

- Konsentrasi EM4

- Limbah padat organik

Alat dan Bahan

: $2 \%, 3 \%, 4 \%, 5 \%$, dan $6 \%{ }^{[14]}$

: Sayur Kubis, Sawi dan Selada

- Alat yang digunakan:

Gelas ukur, karet, kertas pH, pisau, Polybag, sprayer, termometer, timbangan

- Bahan yang digunakan:

Arang sekam, EM4, limbah sayur kubis, limbah sayur sawi, limbah sayur selada

\section{Prosedur penelitian}

Pembuatan Kompos dari limbah sayur dilakukan dengan cara Preparasi Bahan dan Alat, Mengencerkan EM4 menggunakan air $50 \mathrm{~mL}$ dan Pembuatan Kompos. Setelah kompos jadi akan dilakukan pengujian (pH dan suhu) setiap dua hari sekali selama 14 hari, kandungan N, P dan K.

1. Mengumpulkan limbah sayur kubis, sawi, dan selada dari pasar tradisional

2. Memotong kecil-kecil dengan ukuran $\pm 1 \mathrm{~cm}$ setiap sayuran ${ }^{[10]}$

3. Mempersiapkan arang sekam dan EM4

4. Massa Kompos $1 \mathrm{~kg} /$ polybag ${ }^{[5]}$

5. Memasukkan setiap sayuran yang telah dipotong ke dalam polybag dengan massa 500 gram dan ditambah dengan 500 gram arang sekam ${ }^{[13]}$

6. Menambahkan EM4 dengan variasi konsentrasi $2 \%, 3 \%, 4 \%, 5 \%$, dan $6 \%$ sebanyak $50^{[14]}$

7. Diaduk hingga merata dan tutup polybag karena menggunakan proses anaerob

8. Menunggu hingga 14 hari sampai kompos matang ${ }^{[15]}$

9. Setiap 2 hari sekali ada pengecekan suhu, $\mathrm{pH}$ agar suhu kompos stabil dan melakukan proses pembalikan kompos dengan cara menyemprotkan EM4 dan pembukaan polybag ${ }^{[16]}$

10. Melakukan Analisa dari kompos tersebut dengan pengujian kadar unsur hara makro yaitu (kandungan N,P, $\mathrm{K}$,) dan Analisa Fisik kompos (bau, warna, $\mathrm{pH}$ dan suhu).

\section{Hasil}

\section{Hasil Analisa Kadar Nitrogen}

Sesuai standart SNI : 19-7030-2004 tentang kompos bahwa kadar Nitrogen minimal 0,40\%. Dari hasil analisa pada grafik 1. berikut didapatkan presentase pada kadar nitrogen terjadi kenaikan, sehingga kadar nitrogen pada kompos yang kami teliti memenuhi syarat SNI kompos. 


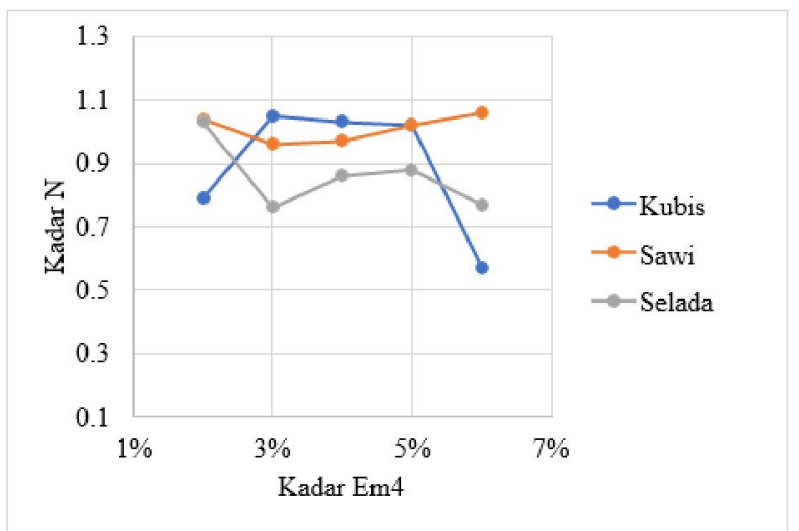

Grafik 1. Kadar nitrogen pada kompos

Pada Grafik 1. hasil analisa yang telah didapatkan bahwa kadar nitrogen tertinggi didapatkan pada sawi dengan konsentrasi $6 \%$ EM4 yaitu sebanyak 1,06\% dan kadar nitrogen terendah yaitu kubis dengan konsentrasi $6 \%$ EM4 yaitu sebanyak $0,56 \%$ dimana dari hasil diatas kadar tertinggi dan terendah sudah melampui batas minimum SNI kompos yaitu $0,40 \%$

Hasil diatas memberikan kecenderungan penurunan kadar Nitrogen selama proses pengkomposan, tetapi hasil tersebut menunjukkan terjadinya kenaikan, jika distandarkan dengan SNI, karena hal ini disebabkan sedikitnya jumlah ammonia dan nitrogen yang terlepas ke udara karena proses dekomposisi mikroorganisme dan terperangkapnya di dalam pori-pori tumpukan kompos yang sangat kecil ${ }^{[5]}$. Oleh sebab itu faktor yang diduga pula dapat menyebabkan perbedaan kandungan nitrogen pada beberapa sampel berbahan baku limbah sayuran tersebut dapat dikarenakan adanya proses dekomposisi yang kurang sempurna sebab dari masing-masing variable yang menggunakan konsentrasi em4 dan dari jenis- jenis sayuran yang berbeda-beda ${ }^{[17]}$.

Hasil Analisa Kadar Phospor

Sesuai standart SNI : 19-7030-2004 tentang Standar Nasional Indonesia mengenai kadar Phospor minimal $0,10 \%$. Dari hasil analisa pada grafik 2 berikut terlihat terjadinya penurunan kadar Phospor selama proses pengkomposan ,tetapi jika distandarkan dengan SNI, kadar phospor pada kompos yang kami teliti memenuhi syarat SNI kompos.

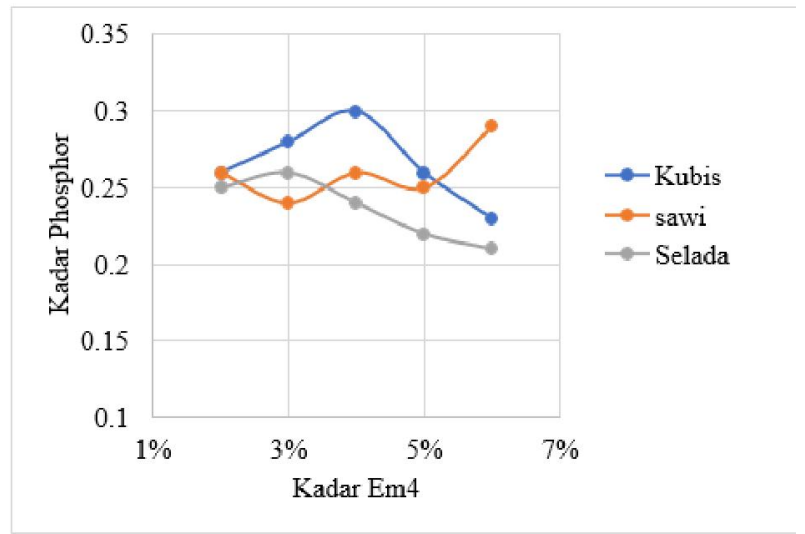

Grafik 2. Kadar phospor pada kompos

Pada Grafik 2 hasil analisa yang telah didapatkan bahwa kadar Phosfor tertinggi didapatkan pada kubis dengan konsentrasi 5 \% EM4 yaitu sebanyak 0,30 \% dan kadar Phosfor terendah yaitu selada dengan konsentrasi $6 \%$ EM4 yaitu sebanyak $0,22 \%$ dari hasil diatas hasil kadar tertinggi dan terendah sudah melampui batas minimum SNI kompos yaitu 0,10\%.

Hal ini disebabkan karena proses pelapukan yang terjadi pada materi kompos menjadi penyebab kadar fosfor menjadi tinggi. Pada tahap pematangan kompos,mikroba akan mati dan kadar fosfor di dalam mikroba akan tercampur dengan materi kompos,sehingga dengan demikian akan langsung meningkatkan kadar fosfor di dalam kompos ${ }^{[18]}$. Kadar fosfor yang tinggi juga bisa dikaitkan dengan kadar nitrogen yang terkandung dalam kompos. Dengan semakin tinggi kadar N total maka jumlah mikroba juga akan semakin banyak,sehingga dengan 
banyaknya mikroba, fosfor yang dirombak juga meningkat, dan hal ini menjadi salah satu penyebab kadar fosfor dalam kompos menjadi tinggi ${ }^{[19]}$.

Hasil Analisa Kadar Kalium

Sesuai standart SNI : 19-7030-2004 tentang Standar Nasional Indonesia mengenai kadar kalium minimal 0,20\%. Dari hasil analisa pada grafik 3 menunjukkan kecenderungan terjadinya penurunan kadar Kalium selama proses fermentasi pembuatan kompos, tetapi kadar kalium yang terbentuk, pada kompos yang kami teliti memenuhi syarat SNI kompos.

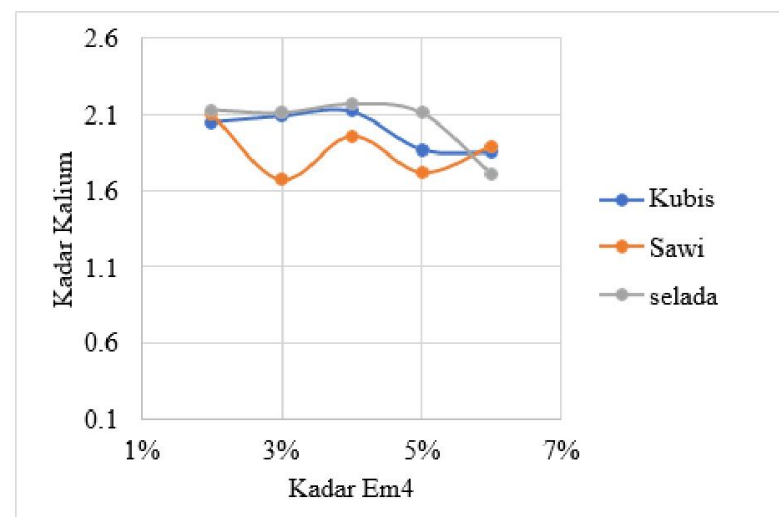

Grafik 3. Kadar kalium pada kompos

Pada hasil analisa yang telah didapatkan bahwa kadar kalium tertinggi didapatkan pada kubis dengan konsentrasi $4 \%$ EM4 yaitu sebanyak 2,12\% dan kadar kalium terendah yaitu selada dengan konsentrasi $5 \%$ EM4 yaitu sebanyak 1,17\% dari hasil diatas hasil kadar tertinggi dan terendah sudah melampui batas minimum SNI kompos yaitu $0,20 \%$

Kalium pada kompos berasal dari materi dasar kompos yang berupa sayuran hijauan yang di dalamnya sudah terdapat unsur K, tetapi unsur Ktersebut masih dalam bentuk bahan organik kompleks sehingga bersifat tidak tersedia bagi tanaman ${ }^{[20]}$. Pada dasarnya dalam bahan organik sudah terdapat kandungan kalium, namun kalium tersebut masih dalam bentuk organik kompleks sehingga tidak dapat diserap langsung olah tanaman. Dengan terjadinya proses dekomposisi, bahan organik kompleks tersebut akan terurai menjadi bahan organik yang lebih sederhana sehingga menghasilkan unsur kalium yang dapat diserap oleh tanaman. Bagi tamanam, kalium memiliki peranan penting dalam proses fotosintesis dalam pembentukan protein dan selulosa yang berfungsi untuk memperkuat batang tanaman. Semakin tinggi kadar kalium dalam kompos maka semakin baik bagi pertumbuhan batang tanaman ${ }^{[21]}$.

Hasil Analisa Suhu

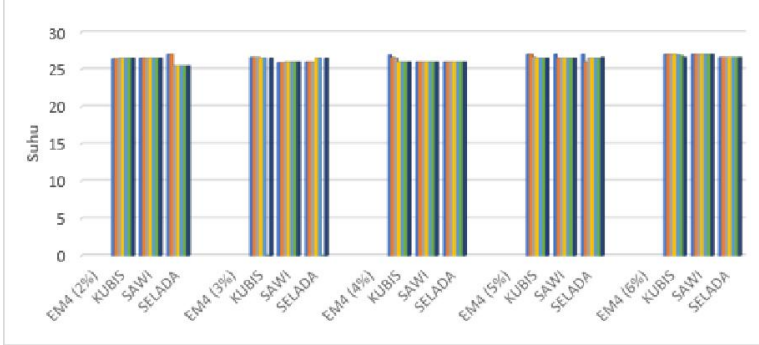

Grafik 4. Suhu pada kompos (pengecekan 2 hari sekali)

Pada Grafik 4 hasil analisa yang telah didapatkan bahwa memperlihatkan suhu yang didapatkan rata-rata sekitar $26-27{ }^{\circ} \mathrm{C}$ dan tidak ada signifikan kenaikan suhu. Hasil suhu yang didapatkan relative rendah dan menurut ${ }^{[5]}$. rendahnya suhu kompos diduga disebabkan karena jumlah limbah pada proses pengomposan tidak cukup memeberikan proses insulasi panas dan disini hasilnya termasuk kedalam fase mesofilik yaitu $23-45{ }^{\circ} \mathrm{C}$ dimana tidak lebih dari $45^{\circ} \mathrm{C}$, sehingga diduga mikroorganisme pengurai yang mampu berkembang biak hanya bakteri-bakteri mesofilik. Peningkatan suhu terjadi karena aktivitas bakteri dalam mendekomposisi bahan organik. Kondisi mesofilik lebih efektif karena aktivitas mikroorganisme didominasi protobakteri dan fungi. 
Pembalikan yang dilakukan dalam proses pengomposan mengakibatakan temperatur turun dan kemudian naik $\operatorname{lagi}^{[22]}$.

Hasil Analisa $\mathrm{pH}$

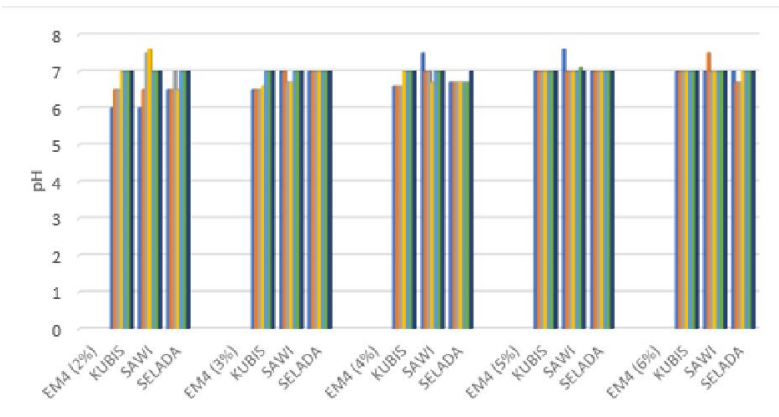

Grafik 5. pH pada kompos (pengecekan 2 hari sekali)

Pada Grafik 5 hasil analisa yang telah didapatkan bahwa memperlihatkan $\mathrm{pH}$ rata - rata 6 - 7,6 dan dari hasil tersebut pH kompos yang ideal berdasarkan standar kualitas kompos SNI : 19-7030-2004 yang berkisar antara 6,8 hingga maksimum 7,49. Maka pada penelitian ini semua sampel telah memenuhi syarat SNI dikarenakan memiliki rata-rata $\mathrm{pH}$ yang tidak lebih dari 7,49.

Peningkatan dan penurunan $\mathrm{pH}$ juga merupakan penanda terjadinya aktivitas mikroorganisme dalam menguraikan bahan organik ${ }^{[23]}$. Perubahan $\mathrm{pH}$ juga menunjukkan aktivitas mikroorganisme dalam mendegradasi bahan organik ${ }^{[24]}$. Pada penelitian ini kebanyakan berkisar pada $\mathrm{pH} 7$ yang dimana menunjukan bahwa $\mathrm{pH}$ tersebut merupakan $\mathrm{pH}$ netral. Nilai $\mathrm{pH}$ yang berada di kisaran netral akan mudah diserap dan digunakan tanaman, serta berguna untuk mengurangi keasaman tanah karena sifat asli tanah adalah asam. Kondisi asam pada proses pengomposan biasanya diatasi dengan pemberian kapur. Namun, dengan adanya pantauan suhu 2 hari sekali dan perlakuan bolak-balik bahan kompos secara tepat waktu dan benar sudah dapat mempertahankan kondisi $\mathrm{pH}$ tetap pada netral.

\section{Hasil Analisa Warna dan Bau}

Kualitas fisik kompos memenuhi syarat kriteria SNI 19-7030- 2004. Kompos memiliki bau seperti tanah, karena materi yang dikandungnya sudah memiliki unsur hara tanah dan warna kehitaman yang terbentuk akibat pengaruh bahan organik yang sudah stabil. Sementara, tekstur kompos yang halus terjadi akibat penguraian mikroorganisme yang hidup dalam proses pengomposan ${ }^{[25]}$. Kualitas fisik kompos yang dihasilkan memberikan gambaran kemampuan masing-masing agen dekomposer dalam mendekomposisi materi organik pada sampah [26].

\section{Kesimpulan}

Berdasarkan hasil penelitian yang telah dilakukan didapatkan beberapa kesimpulan sebagai berikut:

1. Hasil Analisa kualitas fisik dari kompos ( $\mathrm{pH}$, suhu, warna dan bau) dimana $\mathrm{pH}$ rata-rata sekita 6-7,5 suhu 26$27^{\circ} \mathrm{C}$ memiliki warna kehitaman, bau seperti tanah sudah memenuhi kriteria SNI 19- 7030-2004.

2. Sampel yang memiliki kadar nitrogen tertinggi diperoleh sawi dengan konsentrasi $6 \%$ em 4 dengan kadar persen sebesar $1,06 \%$

3. Sampel yang memiliki kadar phosphor tertinggi diperoleh kubis dengan konsentrasi $4 \%$ em 4 dengan kadar persen $0,30 \%$

4. Sampel yang memiliki kadar kalium tertinggi diperoleh selada dengan konsentrasi $4 \%$ em 4 dengan kadar persen $2,17 \%$

5. Dari hasil uji diatas kompos yang kami buat sudah sesuai dan memenuhi kriteria SNI 19- 7030-2004.

\section{Ucapan Terima Kasih}

Kami mengucapkan terimakasih kepada khususnya Laboratorium Mikrobiologi, Prodi Teknik Kimia, Fakultas Teknologi Industri Institut Teknologi Nasional Malang yang telah menyediakan tempat untuk melaksanakan penelitian.

\section{Daftar Pustaka}

[1] S. R. Wulan, "Pemanfaatan Sampah Organik Untuk Pengolahan Kompos.," vol. 1, 2020.

[2] S. L, "Pengelolaan Sampah Dengan Cara Menjadikannya Kompos,” Kesehat. Lingkung., vol. 2 , 2005.

[3] A. H. Permana and R. S. Hirasmawan, "Pembuatan Kompos Dari Limbah Padat Organik Yang Tidak Terpakai (Limbah Sayuran Kngkung, Kol, dan Kulit Pisang),” 2015.

[4] S. Teti, Agustin, and Heny, Bebas Sampah dari Rumah. Jakarta, 2014. 
[5] Suwantatanti and W. P, "Pemanfaatan MOL Limbah Sayur pada Proses Pembuatan Kompos," vol. 40, 2017.

[6] B. N. Widarti, W. K. Wardhini, and E. Surwono, "Pengaruh Rasio C/N Bahan Baku Pada Pembuatan Kompos Dari Kubis dan Kulit Pisang,” Integr. Proses, vol. 5, 2015.

[7] H. Eko, Sawi dan Selada. Jakarta, 2010.

[8] E. Sitompul, I. W. Wardhana, and E. Sutrisno, "Studi Identifikasi Rasio C/N Pengolahan Sampah Organik Sayuran Sawi, Daun Singkong, dan Kotoran Kambing Dengan Variasi Komposisi Menggunakan Metode Vermikomposting," Tek. Lingkung., vol. 6, 2017.

[9] S. Soeleman and D. Rahayu, Halaman Organik. Jakarta, 2013.

[10] Indriani and Y. Hety, Membuat Pupuk Organik Secara Singkat. Jakarta, 2007.

[11] N. Azizah, Al-Baaarri, and M. S, "Pengaruh Lama Fermentasi Terhadap Kadar Alkohol, pH, dan Produksi Gas Pada Proses Fermentasi Bioetanol Dari Whey Dengan Subtitusi Kulit Nanas," Apl. Teknol. Pangan, vol. 1, 2012.

[12] Onggo, T. M. Kusumiyati, and A. Nurfitriana, "Pengaruh penambahan arang sekam dan ukuran polybag terhadap pertumbuhan dan hasil tanaman tomat kultivar 'Valouro' hasil sambung batang," 2017.

[13] S. Ahmad, "Pembuatan Pupuk Organik Dari Kotoransapi Dan Jerami Padi Dengan Proses Fermentasi Menggunakan Bioaktivator M-Dec," vol. 5, 2020.

[14] C. Rulyana, Nurjazuli, and T. Joko, "Variasi konsentrasi em4 dalam proses pembuatan kompos lindi," 2017.

[15] Yaman and M. Aman, Teknologi Penanganan, Pengolahan Limbah Ternak Dan Hasil Samping Perternakan. 2019.

[16] S. F. L, "Kualitas Produk Kompos Dan Karakteristik Proses Pengomposan Sampah Kota Tanpa Pemilahan Awal," vol. 11, 2010.

[17] T. Nur, A. R. Noor, and M. Elma, "Pembuatan Pupuk Organik Cair Dari Sampah Organik Rumah Tangga Dengan Penambahan Bioaktivator EM4 (Effective Microorganisms)," vol. 5, 2016.

[18] A. A. N. Supadma and D. N. Arthagama, "Uji Formulasi Kualitas Pupuk Kompos Yang Bersumber Dari Sampah Organik Dengan Penambahan Limbah Ternak Ayam, Sapi, Babi, dan Tanaman Pahitan,” 2008.

[19] E. T. Marlina, Biokonservasi Limbah Industri Peternakan. Bandung, 2009.

[20] R. Y. Cesaria, R. Wirosoedarmo, and B. Suharto, "Pengaruh Penggunaan Starter Terhadap Kualitas Fermentasi Limbah Cair Tapioka Sebagai Alternatif Pupuk Cair," 2019.

[21] N. Ekawandani and A. A. Kusuma, "Pengomposan Sampah Organik (Kubis dan Kulit Pisang) Dengan Menggunakan EM4,” 2018.

[22] E. S. Pandebesie and D. Rayuanti, "Pengaruh Penambahan Sekam Pada Proses Pengomposan Sampah Domestik," Lingkung. Trop., 2013.

[23] F. Firdaus, "Kualitas Pupuk Kompos Campuran Kotoran Ayam dan Batang Pisang Menggunakan Bioaktivator MOL Tapai," 2011.

[24] A. Ismayama, N. S. Indrasti, Suprihatin, and Dkk, "Faktor Rasio C/N Awal dan Laju Aerasi Pada Proses Cocomposting Bagasse dan Blotong," Teknol. Ind. Pertan., 2012.

[25] Isroi, Kompos. Bogor: Balai Penelitian Bioteknologi Perkebunan Indonesia, 2008.

[26] Sulistyawati, Endah, Mashita, and Dkk, "Pengaruh Agen Decomposer Terhadap Kualitas Hasil Pengomposan Sampah Organik Rumah Tangga,” 2008. 